\title{
The Value Of Partnership In Offshoring
}

Jeremy St. John, Texas A\&M University-Commerce, USA

Carl S. Guynes, University of North Texas, USA

Richard Vedder, University of North Texas, USA

\begin{abstract}
Partnership or strategic partnership is a label attributed to client-vendor relationships characterized as highly involved. This high involvement or collaboration is considered a partnership quality. This study uses the social exchange theory to examine the relationship between clients and vendors as partners in offshoring. Social exchange theory requires that as members of an exchange relationship receive benefit, they must return an equivalent amount of benefit to maintain relationship equilibrium (Homans, 1958). Trust is an important element in exchange relationships because it helps to ensure equilibrium. Management of the client-vendor relationship is critical for the success of the IT offshoring arrangement.
\end{abstract}

Keywords: Offshoring; Partnership; Client-Vendor; Social Exchange Theory

\section{INTRODUCTION}

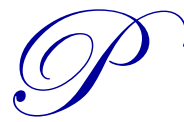

artnership is defined as the collaborative efforts of both the client and vendor in the attainment of a mutually beneficial goal (Fjermestad \& Saitta, 2005). Partnership or strategic partnership is a label attributed to client-vendor relationships characterized as highly involved. This high involvement or collaboration is considered a partnership quality. On the other end of the spectrum are simple outsourcing relationships, relationships guided by strict contracts with minimal interaction between the client and vendor companies. This study uses social exchange theory to examine the relationship between clients and vendors as partners in offshoring. Willcocks and Choi (1995) found that a necessary condition for a "strategic partnering outsourcing arrangement" to succeed is effective interaction at a cooperative level and that a properly constructed contract is just not enough.

Management of the client-vendor relationship is critical for the success of the IT offshoring arrangement. The variables associated with offshoring relationships have changed as offshoring has progressed from simple contracting with outside vendors to longer-term, more involved relationships between client and vendor. Instead of performing simple, non-critical tasks, these new relationships involve more complex, critical tasks requiring a strategic partnership rather than just a contract. A study by Aron \& Singh (2005) found that cost is no longer the most critical offshoring variable and that although cost savings still plays an important role in outsourcing, strategic goals are usually the motivating object today.

\section{PARTNERSHIP COMMUNICATION}

Communication is an important factor in offshoring relationships. Meaningful communication is a necessary antecedent of trust. Utilizing a model derived from Transaction Cost Economics and Social Exchange Theory, Young-Ybarra, and Wiersenna (1999) examined strategic flexibility in IT alliances. They found that the level and quality of communication between the partners in a strategic alliance is positively related to organizational-level trust in the vendor. They also found that communication is positively related to trust. In addition to being important to trust, communication has been linked to partnership and that, ultimately, communication is an important determinant of outsourcing.

The definition of communication used by Anderson and Narus (1990) specified that information is shared both formally and informally. The kinds of information shared should not be limited to strictly operational information, but should also include exchanging things such as desires and needs. This is defined as either a formal or informal, two-way exchange of information, operational or otherwise, that occurs between the client and vendor. 


\section{TRUST AND PARTNERSHIP}

Social exchange theory requires that as members of an exchange relationship receive benefit, they must return an equivalent amount of benefit to maintain relationship equilibrium (Homans, 1958). Trust is an important element in exchange relationships because it helps to ensure equilibrium. Members of an exchange relationship are willing to give more benefit than they are currently receiving if they trust that they will see an increase of similar proportion. This study adopts Bromiley and Cumming's (1993) definition of trust which states, "an individual's belief or a common belief among a group of individuals that another individual or group (i) makes good faith efforts to behave in accordance with any commitments both explicit or implicit, (ii) is honest in whatever negotiations preceded such commitments, and (iii) does not take excessive advantage of another even when the opportunity is available." This definition emphasizes good faith efforts, honesty in negotiations, and not taking advantage of situations.

Many outsourcing failures are attributed to the failure of relationships, specifically the lack of trust between vendor and client. Grover et al (1996) identified trust as a significant factor associated with laying a basis for building a relationship. Trust was also found to be a significant factor in managing an ongoing relationship. Trust in inter-organizational exchanges (offshoring, for example) is linked to performance and clearly matters. In higher commitment client-vendor relationships, trust, rather than incentives and penalties, becomes an important mechanism to ensure that the vendor's interests coincide with those of the client. Ultimately, trust is an important component of the quality of the partnership which determines outsourcing success.

Shared values refers to the "extent to which partners have beliefs in common about what behaviors, goals, and policies are important or unimportant, appropriate or inappropriate, and right or wrong" (Morgan \& Shelby, 1994). Values are a reflection of organizational culture. Social exchange theory describes this commonality of values as cohesion. The result of cohesion is conformity to norms (Homans, 1958). One aspect of norms is the notion of shared values. Organizational behavior literature suggests that exchange partners that share values or are cohesive (to use a term from social exchange theory) will be more committed to the relationship (Morgan \& Shelby, 1994). Young-Ybarra, and Wiersenna (1999) found shared values between organizations to be positively related to organization-level trust. Morgan and Shelby (1994) found a positive relationship between shared values and relationship commitment and between shared values and trust.

\section{COLLABORATIVE RELATIONSHIPS}

In St.John's (2008) study, some variables considered important, based on social exchange theory, were not used because they were not supported by the literature. For example, length of relationship - an indicator of a strategic partnership-type relationship - was excluded because of a lack of support in the literature on offshoring relationships. Length of relationship was also dropped as a partnership metric because of a lack of support (St. John, 2008). Lee and Kim (2004) also found no support for "age of relation" in their study. One possible explanation for the lack of support for the age of relation may be the newness of the strategic partnership type of offshoring relationship. Independent variables included in this study were Communication, Trust, Shared Values, Dependence, and Power.

A review of the literature shows that in the realm of offshoring, many of the client-vendor relationships have been progressing from less involved relationship strategies to more collaborative strategic partnerships. It is also well established that the relationship between the vendor and client plays a critical role in the success or failure of the offshore outsourcing arrangement (Kern, 1997; Lee \& Kim, 2004; Lacity \& Willcocks, 1998). However, when it comes to identifying exactly what the ideal client-vendor relationship should look like, the literature is not only vague but, at times, contradictory.

Lee et al (2004) identified two types of outsourcing relationships - conventional contract, which is associated with higher goal conflict, and strategic joint venture, which is associated with lower goal conflict and a higher level of partnership. They identified three types of outsourcing strategies: 
1. The first, based on Transaction Cost Economics (TCE) which focuses on the make or buy decision, is the "buy-in" control structure.

2. The second, based on Residual Rights theory which is concerned primarily with asset ownership, is the "fee-for-service" control structure.

3. The third outsourcing strategy is the "partnership" control structure. With the partnership control strategy, authority is internalized within the relationship and resources are voluntarily allocated to benefit the partnership

Consistent with Lee \& Kim (2004), a 2005 study by CIO magazine and MIT's Center for Information Systems Research identified three categories of outsourcing arrangements differentiated by the complexity of the work and the associated, necessary complexity of the relationship. The first category - transactional outsourcing deals with outsourcing simple processes that have well defined business rules. Transactional outsourcing arrangements were found to be successful 90 percent of the time. The second category - co-sourcing alliances involve client and vendor jointly managing projects and were found to be successful only 63 percent of the time. The final category - strategic partnerships - involved a single outsourcer taking responsibility for a large number of IT services. The study found that strategic partnerships - the most complicated type of outsourcing relationship were successful only 50 percent of the time but had the most potential for benefit (Overby, 2007).

A higher level of partnership between the client and the vendor implies lower conflict of their individual goals; in other words, more synergy (Lacity and Willcocks, 1998). Although it is the more difficult and costly relationship to maintain, this resulting synergy would seem to be of great value with the newer highly complex highvalue offshoring arrangements. In fact, as McFarlan and Nolan (1995) conclude, what determines the success or failure of the offshoring arrangement is managing the relationship less as a contract and more as a strategic alliance.

\section{CONCLUSIONS}

In their organizational-level survey of service quality, level of outsourcing, partnership and outsourcing success, Grover et al (1996) found a very high correlation between partnership (a mediating variable between level of outsourcing and outsourcing success in their model) and outsourcing success. This finding supports our hypothesis that partnership will be correlated with offshoring success and for the mediating role of partnership. Further support for the mediating role of partnership between relationship variables and offshoring success comes from industry. Joe Hogan, a vice president of worldwide marketing, strategy and alliances for HP Managed Services within HP Services states that an outsourcing partnership takes trust, collaboration, communication and chemistry to be successful (Hogan, 2005).

In higher commitment client-vendor relationships, trust, rather than incentives and penalties, becomes an important mechanism to ensure that the vendor's interests coincide with the client's interests. Ultimately, trust is an important component of the quality of the partnership which determines outsourcing success.

\section{AUTHOR INFORMATION}

Jeremy St. John is an Assistant Professor of Management Information Systems at Texas A\&M UniversityCommerce. He received his Ph.D. from the University of North Texas. His research interests include information technology offshoring, process virtualization, and supply chain management.

C. Stephen Guynes is a Regents Professor of Information Systems at the University of North Texas. He received a doctorate in quantitative analysis from Texas Tech University. Dr. Guynes' areas of specialization are client/server computing, end-user computing, data administration, and information resource management. His most recent research efforts have been directed in the areas of client/server computing and data administration. Some of the journals in which Dr. Guynes has published include Communications of the ACM, Information \& Management, The Journal of Information Systems Management, Journal of Accountancy, Journal of Systems Management, The Journal of Database Management, The CPA Journal, The Journal of Computer Information Systems, Information Strategy, Computers and Security, and Computers and Society. E-mail: Steve.Guynes@unt.edu (Corresponding author) 
Richard G. Vedder is a Professor of Information Systems at the University of North Texas. He received his Ph.D. from the University of Arizona. His research interests include multimedia systems, knowledge-based systems, impact of new technologies and competitive intelligence. He has published articles in Decision Sciences, Communications of the ACM, Computers and Society, IEEE Transactions on Systems, Man and Cybernetics, Expert Systems, and Journal of Information Systems Management.

\section{REFERENCES}

1. Anderson, J.C. \& Narus, J.A. (1990). A model of distributer firm and manufacturer firm working partnerships. Journal of Marketing, 54:1, 42-58.

2. $\quad$ Aron R., \& Singh, J. (2005). Getting offshoring right. Harvard Business Review 83, 135-147.

3. Bromiley, P., \& Cummings, L. L. (1993). Organizations with trust: Theory and measurement. Minneapolis: University of Minnesota. Paper presented at the 53rd annual meeting of the Academy of Management, Atlanta, GA.

4. Fjermestad, J. \& Saitta, J. A. (2005). A strategic management framework for IT outsourcing: A review of the literature and the development of a success factors model. Journal of Information Technology Cases and Applications Research 7(2), 42-60.

5. Grover, V., Cheon, M.J., \& Teng, J.T.C. (1996). The effect of service quality and partnership on the outsourcing of information systems functions. Journal of Management Information Systems, 12(4), 89-116.

6. Hogan, J. (2005). Strategic outsourcing: The importance of choosing the right partner, Computerworld, (February 28).Homans, G. (1958). Social behavior as exchange, The American Journal of Sociology 63(6), 597-606.

7. Kern, T. (1997). The gestalt of an information technology outsourcing relationship: An exploratory analysis. $18^{\text {th }}$ International Conference on Information Systems, Atlanta, Georgia, 37-58.

8. Lacity, M.C., \& Willcocks, L. P. (1998). An empirical investigation of information technology sourcing practices: lessons from experience. MIS Quarterly, (9).

9. Lee, J.N., Miranda, S.M., \& Kim, Y.M. (2004). IT outsourcing strategies: Universalistic, contingency, and configurational explanations of success. Information Systems Research, 15(2), 110-131.

10. McFarlan, W. F., \& Nolan, R. L. (1995). How to manage an IT outsourcing alliance, Sloan Management Review, 36(2), 9-23.

11. Morgan, R. M. \& Shelby, D. H. (1994). The commitment-trust theory of relationship marketing. Journal of Marketing, 58(7), 20-38.

12. Overby, S. (2007). ABC - An introduction to outsourcing, CIO. Retrieved April 1, 2007 from http://www.cio.com/article/40380/ABC_An_Introduction_to_Outsourcing/2.

13. St. John, Jeremy (2008). IT offshoring success: a social exchange perspective, dissertation, University of North Texas.

14. Willcocks, L.P., \& Choi, C.J. (1995). Co-operative partnership and "total" IT outsourcing: From contractual obligation to strategic alliance? European Management Journal 13(1), 67-78.

15. Young-Ybarra, C. \& Wiersma, M. (1999). Strategic flexibility in information technology alliances: The influence of transaction cost economics and social exchange theory, Organization Science 10(4), 439-459. 